\title{
Influence of Four Chemical Nematicides on Meloidogyne incognita Infecting Squash Plants under Greenhouse Conditions
}

El-Sherif, A. G.; O. A. Nassar ; S. B. Gad and H. A. El-Nahas

Nematology Research Unit, Agric. Zoology Dept. Fac. of Agric., Mansoura Univ., Egypt.

Corresponding author: A.G. El-Sherif, Email: elsherif mohammed@yahoo.com .

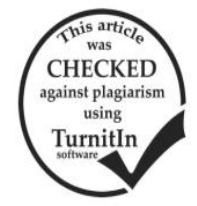

\section{ABSTRACT}

Greenhouse trial was conducted to assess the impact of three chemical nematicides i.e. Furdan, Gupter and Mocap in contrast

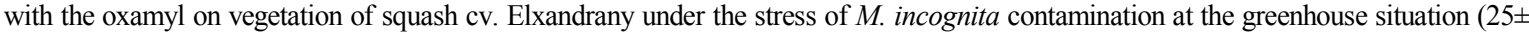
$3^{\circ} \mathrm{C}$ ). The obtained data indicated that all tested nematicides enhanced squash plant growth with various degrees. Mocap surpassed extra chemicals in the increment percentage increase values of plant length (83.65\%), quantity of flowers and leaves $(85.39 \& 56.54 \%)$ sum plant fresh weight $(35.2 \%)$ and shoot arid weight $(87.1 \%)$, and surpassed other chemicals in surpassing final nematode population (96.0\%), number of galls and eggmasses (99.2 \& 99.9\%), followed by Gupter with values of 95.1, 98.6 and $99.1 \%$ for the similar nematode criteria, comparing to nematode only, in that order. Furdan exhibited the slighter values in this respect. The rate of nematode reproduction factor (RF) of $M$. incognita on squash were negatively affected by the tested nematicides and ranged between 0.077 for Furdan and 0.12 for oxamyl vs 1.97 for nematode single-handedly, respectively. The root galls and eggmasses indices of furdan and Gupter were on parity ( $3 \& 3$ and $1 \& 1$ ), respectively vs. $5 \& 5$ for nematode alone. Oxamyl as the typical nematicide gave indices of galls and eggmasses values of $2 \& 2$ vs $5 \& 5$ for nematode alone, respectively.

Keywords: Cucurbitaceae, control, Meloidogyne incognita, Furdan, Gupter, Mocap , oxamyl.

\section{INTRODUCTION}

Cucurbitaceous crops are known for their fruit, consumed raw or cooked, and used for human or animal nourishment. Cucurbitaceae plants had no resistance to Meloidogyne spp (Thomanson and McKiney, 1959). The root-knot nematode, Meloidogyne incognita (Kofoid \&White) Chitwood, is one of the mainly injurious rootknot nematode species, in the last two decades, and one of the most tricky plant diseases to manage. Pytonematodes are at their most weak during their active stage when searching for host plants, and when penetrated a plant roots, control with chemicals is not easy as nematicidal have to be non-phytotoxic and rather systemic. A nematicide that can be securely practical to infected plants and is moved through the roots in sufficiently great amounts to control parasitic nematodes has not been discovered. Oxamyl, is the single marketable product that is used as a foliar treatment, and limited in numerous countries for toxicological effects. There are some nematicides that can be used successfully for phytonematode infecting annual crops (Van Berkum and

\begin{tabular}{|c|c|c|c|c|}
\hline Common name & Formulation & Chemical name & Molecular formula & Chemical Structure \\
\hline $\begin{array}{l}\text { Oxamyl } \\
\text { (Vaydate) }\end{array}$ & $10 \%$ Granules & $\begin{array}{l}\text { :(EZ)-N,N-dimethyl-2- } \\
\text { methylcarbamoyloxyimino-2- } \\
\text { (methylthio)acetamide }\end{array}$ & $\mathrm{C}_{7} \mathrm{H}_{13} \mathrm{~N}_{3} \mathrm{O}_{3} \mathrm{~S}$ & \\
\hline $\begin{array}{l}\text { Carbofuran } \\
\text { (Furadan) }\end{array}$ & $10 \%$ Granules & $\begin{array}{l}\text { (RS)-S-sec-butyl-O-ethyl-2-oxo-1,3- } \\
\text { thiazolidin-3-ylphosphonothioate }\end{array}$ & $\mathrm{C}_{9} \mathrm{H}_{18} \mathrm{NO}_{3} \mathrm{PS}_{2}$ & \\
\hline$\frac{\text { Gupter }}{\text { (Fothiazate) }}$ & $10 \%$ Granules & $\begin{array}{l}\text { 2,2-Dimethyl-2,3-dihydro-1- } \\
\text { benzofuran-7-yl methylcarbamate }\end{array}$ & $\mathrm{C}_{12} \mathrm{H}_{15} \mathrm{NO}_{3}$ & \\
\hline$\frac{\text { Mocap }}{\text { (Ethoprophos) }}$ & $150 \mathrm{GR}$ & $\begin{array}{c}\text { O-ethyl S, S-dipropyl } \\
\text { phosphorodithioate (IUPAC) }\end{array}$ & $\mathrm{C}_{8} \mathrm{H}_{19} \mathrm{O}_{2} \mathrm{PS}_{2}$ & \\
\hline
\end{tabular}

\section{Greenhouse experiment:-}

Thirty four plastic pots $(10 \mathrm{~cm}$-diam.) containing one $\mathrm{kg}$ of steam clean clay loamy soil $(1: 1, \mathrm{v}: \mathrm{v})$ were growing with three squash cv. Eskandrany and irrigated.
Hoestra, 1979), but there appears to be slight vision for management of nematodes in several susceptible crops without repeat application of nematicides. The current research was carried-out to determine the activity of three chemical nematicides i.e. Furdan, Gupter and Mocap comparing to oxamyl on $M$. incognita infecting squash plant in the greenhouse conditions $\left(25 \pm 3^{\circ} \mathrm{C}\right)$,

\section{MATERIALS AND METHODS}

\section{Nematode inoculums:}

The root-knot nematode, $M$. incognita culture was initiated via only eggmass of earlier recognized females (Talyor et al., 1955) and secluded from galled roots of extremely infected tomatoes collected from coleus plants, Coleus blumei in the greenhouse of Nematology Research Unit, Agricultural Zoology Department, Faculty of Agriculture , Mansoura University, where this trial was ended. Nematode inoculum of $M$. incognita was then prepared according to the technique recorded by Hussey and Barker, (1973). 
from nematode inoculation, four chemical nematicides i.e. Furdan, Gupter, Mocap and Oxamyl were individually additional to four seedlings each and mixed with soil. Each treatment was replicated four times. Treatments were as follows:

1- N+ Furdan ( $5 \mathrm{~g} /$ pot $), \quad 2-\mathrm{N}+$ Gupter ( $3 \mathrm{~g} / \mathrm{pot})$,

3- $\mathrm{N}+$ Mocap ( $3 \mathrm{~g} / \mathrm{pot})$, 4- Oxamyl (ox), (0.3 g/ pot)

5- $\mathrm{N}$ alone, and

6- Check.

Treatments were then set in a randomized absolute block design on at the greenhouse at $25 \pm 3{ }^{\circ} \mathrm{C}$ and irrigated with water as required. The experiment were harvested 45 days after nematode inoculation, vegetation criteria such as plant lengths and weights, as well as shoot dry weight were determined. $M$. incognita in $250 \mathrm{~g}$. juveniles were extracted by sieving and modified Baermann- method (Goodey, 1957), counted by Hawksely counting slide under 10x magnification and considered for every pot. Roots of each plant were washed with tap water, fixed and stained according to Byrd et al., 1983. The infected roots examined under a stereomicroscope for developmental stages, females and egg-masses. Data were subjected to analysis of variance (ANOVA) (Gomez and Gomez, 1984) then by Duncan's multiple range tests to compare means (Duncan, 1955).

\section{RESULTS AND DISCUSSION}

Data in Table (1) illustrated the influence of three synthetic_nematicides namely Furdan, Gupter and Mocap in comparison with the standard oxamyl at the optional dose on plant growth response of squash plant cv. Elxandrany beneath the stress of $M$. incognita infection at the greenhouse conditions $\left(25 \pm 3^{\circ} \mathrm{C}\right)$. Data indicated that all tested nematicides enhanced plant growth of squash with different degrees. Mocap surpassed other nematicides in the increment percentage values of plant length $(83.65 \%)$, flowers and leaves numbers $(85.39 \& 56.54 \%)$ whole plant fresh weight $(35.2 \%)$ and shoot dry weight $(87.1 \%)$, followed by that of Gupter nematicide with values that were amounted to $65.42,66.67,44.86,11.12$ and $49.1 \%$, for the similar plant growth characters comparing the check, correspondingly (Table 1). In the meantime, Furdan exhibited the less significant values of plant length $(57.58 \%)$, flowers and leaves numbers $(38.89 \& 35.51 \%)$ total plant fresh weight $(9.56 \%)$ and shoot dry weight $(37.4 \%)$. It is attractive to note that oxamyl as the typical nematicide significantly showed that percentage increase values of plant length (117.69\%), flowers and leaves numbers $(96.3 \& 49.53 \%)$ totality plant fresh weight $(89.5 \%)$ and shoot dry weight (160.8\%) compared to other nematicides as well as nematode alone. Nevertheless, plants free of the nematicides nematode infection recorded extensive percentage increase values of plant length $(7.32 \%)$, number of flowers and leaves $(29.63 \& 26.17 \%)$ whole plant fresh weight $(4.78 \%)$ and shoot dry weight $(28.6 \%)$ when compared to nematode alone (Table 1).

Table 1. Plant growth response of squash plant cv. ELxandrany infected with Meloidogyne incognita as affected by three chemical nematicides in contrast with oxamyl under greenhouse conditions $\left(25 \pm 3^{\circ} \mathrm{C}\right)$.

\begin{tabular}{|c|c|c|c|c|c|c|c|c|c|c|c|c|c|c|}
\hline \multirow{3}{*}{ Treatments } & \multicolumn{13}{|c|}{ *Plant growth response } & \multirow{3}{*}{$\begin{array}{c}* * \\
\text { Inc. } \\
\%\end{array}$} \\
\hline & \multicolumn{2}{|c|}{ Length (cm) } & \multirow{2}{*}{$\begin{array}{c}\text { Total plant } \\
\text { length } \\
\text { (cm) }\end{array}$} & \multirow{2}{*}{$\begin{array}{c}* * \\
\text { Inc. } \\
\%\end{array}$} & \multirow{2}{*}{$\begin{array}{c}\text { No. } \\
\text { of } \\
\text { flowers }\end{array}$} & \multirow{2}{*}{$\begin{array}{c}* * \\
\text { Inc. } \\
\%\end{array}$} & \multirow{2}{*}{$\begin{array}{c}\text { No. } \\
\text { of } \\
\text { leaves }\end{array}$} & \multirow{2}{*}{$\begin{array}{c}* * \\
\text { Inc. } \\
\%\end{array}$} & \multicolumn{2}{|c|}{ Fresh weight(g) } & \multirow{2}{*}{$\begin{array}{c}\text { Total } \\
\text { plant } \\
\text { F.Wt (g) }\end{array}$} & \multirow{2}{*}{$\begin{array}{c}* * \\
\text { Inc. } \\
\%\end{array}$} & \multirow{2}{*}{$\begin{array}{l}\text { Shoot dry } \\
\text { weight } \\
\text { (g) }\end{array}$} & \\
\hline & Shoot & Root & & & & & & & shoot & root & & & & \\
\hline Furdan & $31.72 \mathrm{~b}$ & $11.92 \mathrm{~b}$ & $43.65 \mathrm{bc}$ & 57.58 & $3.75 \mathrm{~b}$ & 38.89 & $14.5 \mathrm{ab}$ & 35.51 & $9.58 \mathrm{c}$ & $1.10 \mathrm{bc}$ & $11.92 \mathrm{c}$ & 9.56 & $0.47 \mathrm{~b}$ & 37.4 \\
\hline Gupter & $31.02 \mathrm{~b}$ & $14.8 \mathrm{~b}$ & $45.82 \mathrm{bc}$ & 65.42 & $4.5 \mathrm{ab}$ & 66.67 & & 44.86 & $10.91 \mathrm{bc}$ & & $12.09 \mathrm{bc}$ & 11.12 & & 49.1 \\
\hline Mocap & $38.87 \mathrm{~b}$ & $12.0 \mathrm{~b}$ & $50.87 \mathrm{~b}$ & 83.65 & $5 \mathrm{ab}$ & 85.19 & $16.7 \mathrm{ab}$ & 56.54 & $13.15 \mathrm{~b}$ & $1.55 \mathrm{~b}$ & $14.71 \mathrm{~b}$ & 35.20 & $4 \mathrm{a}$ & 87.1 \\
\hline Oxamyl & $39.2 \mathrm{~b}$ & $21.1 \mathrm{a}$ & $60.3 \mathrm{a}$ & 117.69 & $5.3 \mathrm{abc}$ & 96.30 & $16.0 \mathrm{ab}$ & 49.53 & $18.9 \mathrm{a}$ & $1.5 \mathrm{~b}$ & $20.4 \mathrm{a}$ & 87.50 & $0.89 \mathrm{~b}$ & 161.8 \\
\hline$* \mathrm{~N}$ alone & $16.3 \mathrm{c}$ & $11.4 \mathrm{c}$ & $27.7 \mathrm{c}$ & 0.00 & $2.7 \mathrm{c}$ & --- & $10.7 \mathrm{~b}$ & ----- & $10.0 \mathrm{c}$ & $1.0 \mathrm{~b}$ & $10.88 \mathrm{~b}$ & ----- & $0.342 \mathrm{a}$ & 0.0 \\
\hline Plant Free & 14.2 & $15.5 \mathrm{bc}$ & $29.7 \mathrm{c}$ & 7.22 & $3.5 \mathrm{abc}$ & 29.63 & $13.5 \mathrm{ab}$ & 26.17 & $9.5 \mathrm{c}$ & $1.9 \mathrm{~b}$ & $11.4 \mathrm{~b}$ & 4.78 & $0.44 \mathrm{~b}$ & 28.6 \\
\hline L.S.D at $0.05 \%$ & 6.74 & 4.52 & 9.39 & --- & 2.58 & --- & 4.19 & --- & 2.28 & 0.46 & 2.67 & --- & 0.23 & $\overline{---}$ \\
\hline
\end{tabular}

$* * \mathbf{N}=1000$ M. incognita $\left(\mathrm{J}_{2}\right)$.

* Means in each column followed by the same letter(s) did not differ at $\mathbf{p}<0.05$ according to Duncan's multiple-range test.

Data in Table (2) documented the efficacy of four chemical nemticides, Furdan, Gupter, Mocap and oxamyl on development and reproduction of $M$. incognita infecting squash plant beneath greenhouse conditions $\left(25 \pm 3^{\circ} \mathrm{C}\right)$. All tested chemical nematicides significantly reduced the immature stages, nematode populations, galls and eggmasses number (Table 2). Mocap surpassed other tested chemicals in surpassing final nematode population $(96.0 \%)$, number of galls and eggmasses/ root system (99.2 \& 99.9\%), then that of Gupter treatment with values of 95.1, 98.6 and $99.1 \%$ for the similar nematode criteria, respectively. Furthermore, Furdan ranked the third in diminishing the same nematode criteria values that amounted to 94.7 , 98.5 and $99.0 \%$ as compared to nematode alone, in that order. Oxamyl was significantly adjusting the nematode parameters with slightly lower values than those of other nematicides since these values were amounted to 93.9, 95.8 and $96.2 \%$ for final nematode population, galls and eggmasses numbers. Moreover, rate of nematode reproduction factor (RF) of $M$. incognita on squash plant were harmfully affected by the tested chemical nematicides. Such rate of nematode reproduction was ranged beginning 0.077 for Furdan and 0.12 for oxamyl in opposition to 1.97 for nematode alone, respectively. It is valuable to note that Mocap represented the lowest values (0.077), whereas oxamyl showed the greatest value (0.12). Meanwhile, indices values of root galls and eggmasses for Furdan and Gupter were on parity ( $3 \& 3$ and $1 \& 1)$, respectively vs. $5 \& 5$ for nematode only. In the meantime, oxamyl as the typical nematicide recorded indices of galls and eggmasses values of $2 \& 2$ vs $5 \& 5$ for nematode alone, respectively. (Table 2). 
Certainly, the utilization of three chemical nematicides i.e. Furdan, Gupter and Mocap comparing to standard oxamyl on squash plant under the stress of $M$. incognita infection indicated that all tested nematicides improved plant growth of squash with different degrees. Mocap treatment surpassed other chemicals in the increment percentage increase values of plant growth parameters and suppressing other tested chemicals insurpassing nematode population followed by that of Gupter treatment. The current results were in agreement with those of Khalil (2013) who stated that oxamyl or fosthiazate recorded the maximum decrease of nematode population. The application of Furdan was the lowest effective treatment against the root-knot nematode population in this investigation. On the other hand, these results are supported by those of Saad et al (2017) who revealed that fenamiphos or oxamyl achieved the highest decrease values of galls and egg-masses. Avermactin has moderately reduction in gall formation and egg-masses. Meanwhile, cadusafos and oxamyl achieved the supreme decrease for eggs per egg-mass.

Table 2. Development and reproduction of Meloidogyne incognita infecting squash plant cv. ELxandrany as affected by three chemical nematicides comparing to typical oxamyl under greenhouse conditions $\left(25 \pm 3^{\circ} \mathrm{C}\right)$.

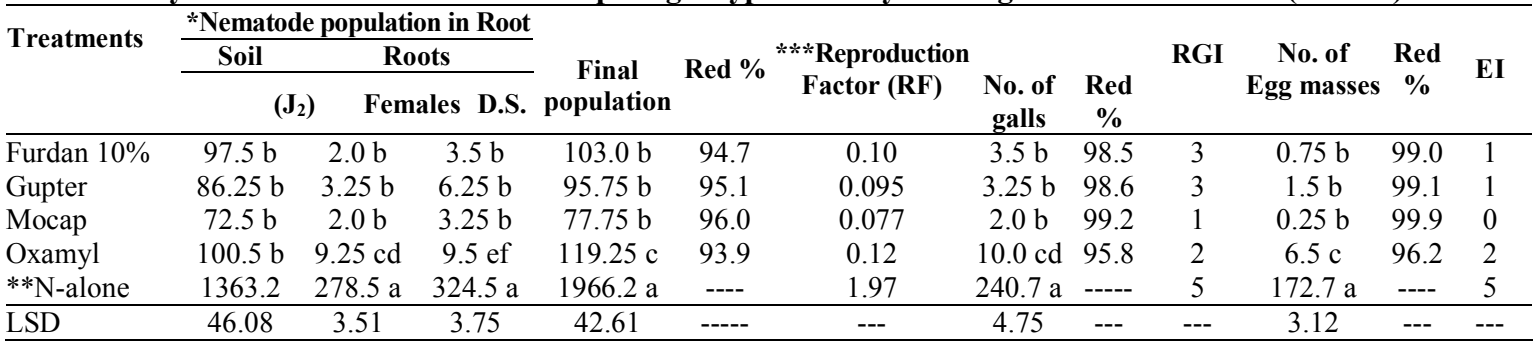

$* * \mathbf{N}=1000$ M. incognita $\mathrm{J}_{2} \quad$ D.V.= Developmental stages.

* Each value is a mean of four replicates. Mean values in each column followed by the same letter(s) did not differ at $P<0.05$ according to Duncan's multiple- range test. $* * *$ Root gall index (RGI) or eggmasses index (EI) : $O=$ No galls or eggmasses, $1=1-2$ galls or eggmasses, $2=3-10$ galls or eggmasses , 3=11-30 galls or eggmasses , 4=31-100 galls or eggmasses and $5=$ More than 100 galls or eggmasses (Taylor and Sasser, 1978).

\section{REFERENCES}

Byrd, D. W.; T. Kirkpatrick, and K. R. Barker, 1983. An improved technique for clearing and staining plant tissues for detection of nematodes. J. Nematol., 15(3)142-143.

Duncan, D.B. (1955). Multiple rang and multiple F-test. Biometrics, 11: 1-42.

Gomez, K. A. and A. A. Gomez, 1984. Statistical Procedures for Agriculture Research. $2^{\text {nd }}$ Ed., June Wiley \& Sons. Inc. New Yourk.

Goodey, J.B. (1957). Laboratory methods for work with plant and soil nematodes. Tech. Bull.No.2 Min.Agric.Fish Ed. London 47 pp.

Hussey, R.S. and K. R. Barker, 1973. A comparison on methods of collecting inocula of Meloidogyne spp. including a new technique. Plant Dis. Reptr., 57: 1025-1908.

Khalil, M. S. (2013). Nematicidal performance of two agrochemicals and spinosad on the root-knot nematode population. Canadian Journal of Plant Protection, 1(5):177-181.
Saad, A. S. A.; Radwan, M. A.; Mesbah, H. A.; Ibrahim, H. S.; Khalil, M. S.(2017). Evaluation of some nonfumigant nematicides and the biocide avermactin for managing Meloidogyne incognita in tomatoes. Pakistan Journal of Nematology .35(1).85-92 .

Taylor, A. L. and J. N. Sasser (1978).Biology, identification and control of root-knot nematodes (Meloidogyne spp.) Raleigh, North Carolina state Univ. Graphics. Raleigh, NC. 111 pp.

Taylor, A. L.; V. H. Dropkin, and G. C. Martin, 1955. Perinial pattern of root-knot nematodes. Phytopathol., (45):26-34.

Thomason I.J. and H. E. McKiney HE 1959. Reaction of some Cucurbitaceae to root-knot nematodes (Meloidogyne spp.). Plant Dis. Rep. 43: 448- 450.

Van Berkum, J.A. \& Hoestra, H. 1979. Practical aspects of the chemical control of nematodes in soil, p. 53154. In D. Mulder, ed. Soil disinfestation. Amsterdam, the Netherlands, Elsevier.

$$
\begin{aligned}
& \text { تأثير اربعة من المبيدات الكيماوية علي نيماتودا تعقد الجذور التي تصيب نبات الكوسة تحت ظروف الصوبة التوبة الزراعية }
\end{aligned}
$$

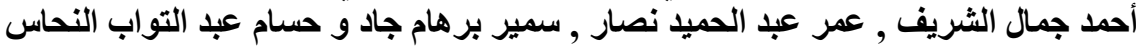

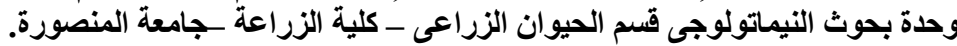

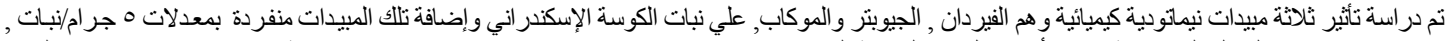

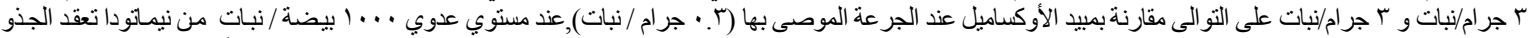

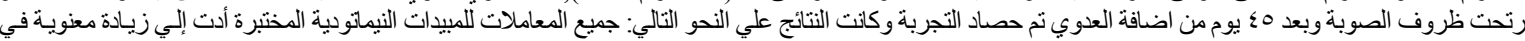

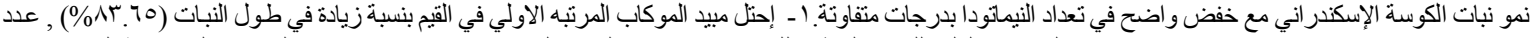

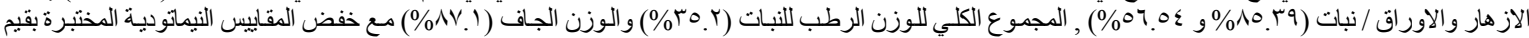

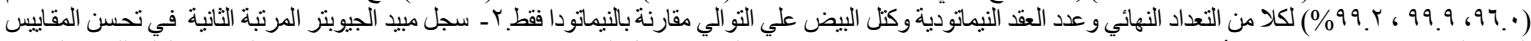

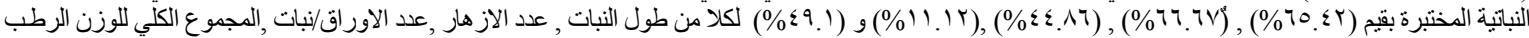

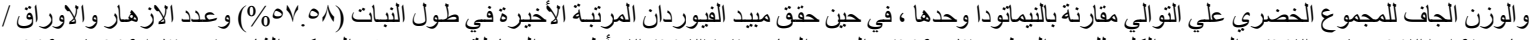

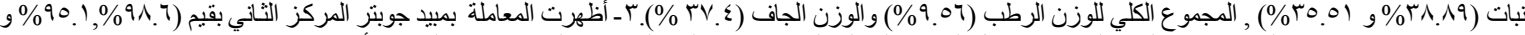

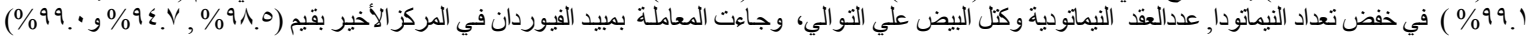

